\title{
Leadership for the church: The shepherd model
}

\begin{tabular}{|c|c|}
\hline \multicolumn{2}{|c|}{$\begin{array}{l}\text { Author: } \\
\text { K. Thomas Resane }{ }^{1}\end{array}$} \\
\hline \multicolumn{2}{|c|}{$\begin{array}{l}\text { Affiliation: } \\
{ }^{1} \text { Department of Systematic } \\
\text { Theology and Christian } \\
\text { Ethics, University of Pretoria, } \\
\text { South Africa }\end{array}$} \\
\hline \multicolumn{2}{|c|}{$\begin{array}{l}\text { Note: } \\
\text { Dr Thomas Resane is } \\
\text { participating as research } \\
\text { fellow of Prof. Dr Danie } \\
\text { Veldsman in the Department } \\
\text { of Systematic Theology and } \\
\text { Christian Ethics, Faculty } \\
\text { of Theology, University of } \\
\text { Pretoria, South Africa. }\end{array}$} \\
\hline \multicolumn{2}{|c|}{$\begin{array}{l}\text { Correspondence to: } \\
\text { Thomas Resane }\end{array}$} \\
\hline \multicolumn{2}{|c|}{$\begin{array}{l}\text { Email: } \\
\text { thomas@aogkempton.org }\end{array}$} \\
\hline \multicolumn{2}{|c|}{$\begin{array}{l}\text { Postal address: } \\
\text { PO Box } 9463, \text { Edenglen } 1613, \\
\text { South Africa }\end{array}$} \\
\hline \multicolumn{2}{|c|}{$\begin{array}{l}\text { Dates: } \\
\text { Received: } 14 \text { Aug. } 2013 \\
\text { Accepted: } 07 \text { Feb. } 2014 \\
\text { Published: } 30 \text { May } 2014\end{array}$} \\
\hline \multicolumn{2}{|c|}{$\begin{array}{l}\text { How to cite this article: } \\
\text { Resane, K.T., 2014, } \\
\text { 'Leadership for the church: } \\
\text { The shepherd model', } \\
\text { HTS Teologiese Studies/ } \\
\text { Theological Studies } 70(1) \text {, } \\
\text { Art. \#2045, } 6 \text { pages. http:// } \\
\text { dx.doi.org/10.4102/hts. } \\
\text { v70i1.2045 }\end{array}$} \\
\hline \multicolumn{2}{|c|}{$\begin{array}{l}\text { Copyright: } \\
\text { (C) 2014. The Authors. } \\
\text { Licensee: AOSIS } \\
\text { OpenJournals. This wor } \\
\text { is licensed under the } \\
\text { Creative Commons } \\
\text { Attribution License. }\end{array}$} \\
\hline \multicolumn{2}{|l|}{ Read online: } \\
\hline aripa & $\begin{array}{l}\text { Scan this QR } \\
\text { code with your } \\
\text { smart phone or } \\
\text { mobile device } \\
\text { to read online. }\end{array}$ \\
\hline
\end{tabular}

The scope of this article is to expand the shepherd model of leadership functions as portrayed by the shepherd metaphor. The identification and the biblical usage of the shepherd and the sheep is explored, with special focus on the role of the shepherd. This role is identified as that of caring, courage, and guidance. The caring function includes activities such as restoration, feeding, watering, grooming, shearing, delivering lambs, leading, and protection. The function of courage focuses on activities of assuming responsibility, serving and participating in change. The function of guidance gives a special highlight on hodegos [leader or guide] - to lead or to guide in regard to a decision or future course of action. This is where the leadership training is based. The conclusion is the call for leaders in the ecclesiastical community to pursue the shepherd-leader model for the advance and the effectiveness of the mission Dei [mission of God] in the world.

\section{Introduction}

There is a general opinion within the ecclesiastical traditions that the church, especially in Africa, is under-led. This is highlighted by some authors, such as John S. Pobee (1992); J.N.K. Mugambi (1995); P.N. Mwaura (1994) and many others writing from the African perspectives. The question of ineffectiveness swings around the capability and the character of leadership. Shepherding is vanishing, and the church remains directionless and under-fed. This dire situation is echoed by Dorothy J. Weaver (2009:9) that 'the Jewish leaders of Matthew's narrative are not fulfilling the leadership role to which they have been called as "shepherds of Israel" (cf. Ezk 34:11-16), because he views them as "harassed and helpless, like sheep without a shepherd" (Ezk 9:36)'.

\section{Definitions and explanations}

There are numerous leadership models in the Bible, such as school of prophets, servant leadership, teacher-learner relationship, disciple-making, coaching, mentoring, amongst others. The focus of this article is that of the shepherd-leader. The natural thought coming to mind in considering leaders as shepherds is Psalm 23. This Davidic Psalm starts with the reassuring assertion that ' $t]$ he Lord is my shepherd; I shall not be in want'. This Psalm is one of the best known and one of the most appreciated pieces of Old Testament literature ever penned. It is David's reflection on God's task as the shepherd-leader for his people. It is a catalogue of lessons learned about the task of leadership from guiding the sheep and a reflection of his critical thinking. 'The Lord is my shepherd' is a picture of caring, courage, and guidance.

In a general sense a shepherd refers to a keeper of sheep. This is the person who tends, feeds, or guards the flocks. The Hebrew word for shepherding is often translated as 'feeding' as it is impressed by the next statement, 'I shall not want' or 'I shall lack nothing' - alluding to the fact that the Psalmist means he will lack neither in this life nor in the next. Further, according to Anderson (1972):

This confidence of the Psalmist is further strengthened by the implicit allusion to the salvation history of the people. Even in the wilderness during the forty years, the Israelites lacked nothing, for God was with them. (pp. 196-197)

This implies the provision of the necessary food for physical nourishment (Dt 2:7). The New Testament Greek root bo [feed] found in boter [a herder] also gives the meaning of feeding or nourishing (Vine 1952:417), emanating from the concept of tending or shepherding. This is expressed by the synoptic gospel writers as they relate to the people tending the pigs in the area of Decapolis.

The Old Testament refers to the shepherd to designate not only persons who herded sheep but also monarchical leaders (2 Sm 5:2) and God himself (Is 40:11; Ps 23:1). The prophetic literature refers to national leaders as shepherds (Ezk 34:1; Jr 23:1) (see Gray n.d.). 
The New Testament has 16 references to 'shepherds'. The shepherds were amongst the first to receive the message of Jesus' birth and visit him (Lk 2:8-20). The shepherd and the sheep relationship is used to illustrate Christ's relationship to his followers who referred to him as 'our Lord Jesus, that great shepherd of the sheep' (Heb 13:20). Jesus spoke of himself as 'the good shepherd who knew his sheep and would lay down his life for them' (Jn 10:7-18). After his resurrection, Jesus commissioned Peter to feed his sheep (Jn 21:1) (see Gray n.d.). In his farewell address to the Ephesian elders, Paul pictured the church and its leaders as a flock with shepherds (Ac 20:28). The Latin word transliterated with 'pastor' means shepherd.

In Jesus' day shepherding was still a vital occupation. The Johannine text (ch. 10) continues the Old Testament notion of the Almighty, Jehovah God as a 'shepherd' (Is 40:10-11; Ps 23:1-4). In this context Jesus is 'the fine shepherd' and often used the qualities of a good shepherd to teach important lessons (see Gray n.d.).

\section{The shepherd's role and functions in the Bible}

The first Bible reference to shepherd is Abel, the son of Adam (Gn 4:2). Shepherding was the chief occupation of the Israelites in the early patriarchal age. Good examples to be referred to are Abraham (Gn 12:16); Rachel (Gn 29:9); Jacob (Gn 30:31-40) and Moses (Ex 3:1). As the biblical history unfolded, cultivation took pre-eminence, and shepherding fell from favour and was assigned to those in the low social ranks of society such as the younger sons, hirelings, and slaves (compare David in 1 Sm 16:11-13). Farmers such as in Egypt even hated shepherds (Gn 46:34) (see Gray n.d.).

The broader functions of the shepherd were to lead the sheep to pastures and water (Ps 23:1) to protect them from wild animals (1 Sm 17:34-35); and to guard them at night, whether in the open (Lk 2:8) or in sheepfolds (Zph 2:6) where they counted them as they entered the fold (Jr 33:13). They took care of the sheep and even carried weak lambs in their arms (Is 40:11) (see Gray n.d.). It is of great interest to note that these functions are contrary to the shepherds of Ezekiel's era, where they received indictment 'through the metaphorical language of 34:2-6. Basically they have served themselves at the expense of their people, rather than serving the people at any cost to themselves' (Wright 2001:275).

The sheep represented wealth because they provided food (milk); clothing (wool and hides); and shelter (leather for tents). Furthermore, sheep played a major role in the Levitical sacrificial system. They were offered as burnt offerings ( $\mathrm{Lv}$ 1:10), sin offerings ( $\operatorname{Lv} 4: 32$ ), guilt offerings ( $\operatorname{Lv} 5: 15$ ), and peace offerings (Lv 22:21) (see Gray n.d.) The Old Testament leadership maxim of the shepherd model is ' $[h]$ e tends his flock like a shepherd: He gathers the lambs in his arms and carries them close to his heart; he gently leads those that have young' (Is 40:11). The sheep were generally the docile animals and easily led and completely at the mercy of their environment and predators.

The two major prophets, Jeremiah and Ezekiel made an extensive reference to the shepherd model of leadership. Ezekiel chooses a shepherd metaphor for kingship that was well-known throughout the ancient Near East, from Babylon to Egypt. In Ezekiel 34, the prophets seems to be having in mind the text of Jeremiah 23:1-6 (Wright 2001:274-276).

The maxim of the New Testament is John 10, especially verses 14 and 16:

I am the good shepherd; I know my sheep and my sheep know me- just as the Father knows me and I know the Father-and I lay down my life for the sheep. I have other sheep that are not of this sheep pen. I must bring them also. They too will listen to my voice, and there shall be one flock and one shepherd.

The shepherd's ongoing challenge was teaching to obey his commands. Good shepherds took tender care of the animals in their charge, even giving them names to which they would respond. The biblical references lead to the conclusion that harmonises with Calvin's (1989:686) questions in the Book IV of his Institutes of the Christian religion:

- Who rules?

- What are they?

- What is their calling?

- What is their office?

- What was the condition of the ancient Church?

The three major shepherd-leader's responsibilities of caring, courage, and guiding are elaborated on.

\section{Caring}

The idea here is that of proistèmi, which carries the meaning of presiding over, to lead, to direct, to protect, or even to sponsor. Basically, as Wright (2001) asserts:

it would involve caring for them properly, by tending their needs and providing good pasture. The New Testament variably and interchangeably attaches the ideas 'to lead' and 'to care for'. (p. 277)

In addition:

The combination of leading and caring that one may see in the New Testament usage agrees well with the principle of Luke 22:26 that the leaders is to be as one who serves. (Bromiley 1985:939)

The caring aspect of shepherd-leadership includes the function of the following.

\section{Restoration}

This restoration entails searching, finding, and bringing home. These are all found and exposited in John 10. Jesus, as the Good Shepherd is anxious to recover or find the lost sheep (Jn 10:11). He leaves the 99 immediately to go after the one who is lost. The shepherd does not give up until the sheep is found. He goes after the sheep 'until he finds it'. The 
shepherd is not angry at the sheep (see Bible Study Planet n.d.). He is joyful when he finds his sheep and delights in bringing it home. Genuine love not only disciplines; it heals and restores. Caring love heals the sorrowing soul unlike any other medicine.

The shepherd-leaders' priority is to help people who have wandered, fallen into the fire, whilst being careful not to get burned themselves or soil their own clean clothes. This implies that leaders within the ecclesiastical context need to be careful about hanging out with false teachers and those who are deceived, as they are also in danger of being deceived. They need to be mindful that they have all wandered at times, they have gone astray, but the point is to return to the Shepherd. It is true that the:

sheep that are temporarily without their shepherd and sheep that are destined for the slaughterhouse due to various hostilities are illustrations of believers who proceed without the light of God's face. (Selderhuis 2007:184)

\section{Feeding}

This refers to the restoration of health, growth and strength. One of the didactic passages in the New Testament regarding shepherd - leadership is John 21:15-17:

When they had finished eating, Jesus said to Simon Peter, 'Simon son of John, do you truly love me more than these?' 'Yes, Lord,' he said, 'you know that I love you.' Jesus said, 'Feed my lambs.' Again Jesus said, 'Simon son of John, do you truly love me?' He answered, 'Yes, Lord, you know that I love you.' Jesus said, 'Take care of my sheep.' The third time He said to him, 'Simon son of John, do you love me?' Peter was hurt because Jesus asked him the third time, 'Do you love me?' He said, 'Lord, you know all things; you know that I love you.' Jesus said, 'Feed my sheep'.

First Jesus says 'feed my lambs'. Emulating the foundational apostles such as Peter, leadership is charged to feed the lambs. Lambs need milk. They need the basics of the Gospel and simple biblical precepts to grow. Shepherd-leaders are then to 'take care of my sheep'. Shepherd-leadership is finally charged to 'feed my sheep'. These are the sheep of the Lord, not the church leaders' sheep. Shepherd-leaders are the oikonomos [caretakers], tasked to manage and to administer the welfare of the sheep that belong to the Master. The point is shepherd-leaders are to move beyond feeding the lambs gala [milk] to feeding the sheep broma [solid food]. Solid food is training in righteousness so that the sheep can be fully equipped, able to stand in the day of testing (see Simpson 2005). They must be fed on the basics and the fundamentals of the biblical dogma, ecclesiastical catechesis, and the apostolic paradosis.

\section{Watering}

When all the flocks were gathered there, the shepherds would roll the stone away from the well's mouth and water the sheep. Then they would return the stone to its place over the mouth of the well. (Gn 29:3)

Water in the Bible is sometimes used to refer to the Holy Spirit, who plays a significant role in salvation processes, for 'in baptism we are born again (Jn 3:5), we are renewed by the Spirit' (Peters 2000:289). It certainly is in the case of water baptism. A shepherd intentionally leads his flock to water regularly for renewal and refreshment. He will roll away the stone covering the well and draw the water for the flocks. In the ecclesiastical leadership context, a shepherd-leader rolls the stones of hard hearts and prepares those hearts to be receptive to the nourishment of the Holy Spirit. This can only be accomplished by rolling away the stone of the 'self' culture so the light of God's written Word can shine through teaching and proper exegesis, through prayer, and living in obedience to the commands of Jesus Christ.

\section{Grooming}

This function involves educating for a future role or function. In general terms, it means giving a neat appearance to someone or something; or caring for one's external appearance. A groom in the olden days referred to someone employed in a stable to take care of the horses. A shepherd grooms his sheep, keeps them clean and free of contamination from the world, the flesh and the devil. He then prepares them through instruction to be disciples, followers of the Good Shepherd, so they will, in turn, go out and minister to others. It was at the climax of his mission on earth that Christ, after grooming his disciples could entrust them with the mandate:

Therefore go and make disciples of all nations, baptizing them in the name of the Father and of the Son and of the Holy Spirit, and teaching them to obey everything I have commanded you. And surely I am with you always, to the very end of the age. (Mt 28:19-20)

\section{Shearing}

This is to cut to the desired shape or thickness using shears. It is a fleecing act to remove wool from the sheep either for good or for bad purpose. At times sheep must be sheared. This is a useful and profitable process for both the sheep and the shepherd. This is an offering to the Good Shepherd. For the benefit of all, the sheep must be sheared. In other words, they must be disciplined, encouraged and rebuked so that they may be fit for service to the Lord. The shepherds of Judah failed to synergise this mutual benefit as it is eluded in Ezekiel 34:3-4.

\section{Delivering lambs}

According to Isaiah 40:11, ' $[h]$ e tends his flock like a shepherd: He gathers the lambs in his arms and carries them close to his heart; he gently leads those that have young'. Shepherdleaders' task is to deliver the lambs. Leadership proclaims the Gospel; the Holy Spirit then convicts the sinner, who eventually becomes a Christian. The leader is in partnership with the Holy Spirit to bring about a new birth. Divine and human instrumentalities cooperate to give new life to the potential follower of Christ. Only the Lord Jesus Christ can save and cause a person to be born again. But when a lamb is newly born, the shepherd-leader still has responsibilities. When lambs are born, they come out naive. They are weak and vulnerable. They are to be guided in commencing the eschatological journey of Christian life. This is called 
discipleship - the eschatological journey towards maturity. Then, when the lamb is relatively mature, it is freed to grow to maturity and live its faith out in action.

\section{Leading}

The shepherd-leader directs the flock in the world, helping them not to be of the world. Leadership determines direction. Following the lead of the Good Shepherd as shepherdleaders, the focus is to lead the sheep to pastures and water. They are taught and restored. They are guided in paths of righteousness. They are protected from wolves and beasts (pseudo-leaders) in the world with the rod and staff. The rod and staff are for disciplining the flock and protection for the flock. This is the provision of good leadership that Wright (2001:277) refers to as 'the necessary work of justice and protection of the weak that needed to go on'.

This shepherd-leader's task calls for the discipline of the sheep to alert them to the pitfalls of the world. This leader task also means directing the flock out and teaching them to stay together in unity. The properly-led sheep cannot erroneously be in unity with wolves (pseudo-leaders) that appear in sheep's clothing, because they possess a strong sense of discernment. Wolves are leaders who pretend to be in unity with the sheep with the destruction and final perdition of the sheep as motive. These wolves masquerade as angels of light by disguising their authenticity and genuineness in areas of prayer, speech, appearance, miracle performance, and so forth. Tenney (1975) reminds us that:

The life of the sheep was dependent upon the power and provision of the shepherd. Their recognition of him and his recognition of them established the relationship. Hearing his voice, following his leading, entering the fold through him, and the refusal to follow others was John's picture of belief. (p. 165)

Generally, there is some symbiotic relationship between the shepherd and the sheep, that is, the leader and the followers. When the two are closely related, the deceiving wolves are exposed by the outcomes of their behaviour. These outcomes are false dogma and didache accompanied by false prophecies. Their actions are nullified by their character. Shepherdleaders are therefore leaders who teach the sheep to be vigilant regarding pseudonymous leaders who deceive by leadership expressed through the lack of kyberneseis [qualities of government] that Paul refers to in 1 Corinthians 12:28-30. This is vital to the caring function, for the capacity to lead is authenticated by the capacity to care. The leadership and the care of the flock (church) cooperate synergistically.

\section{Protection}

This is the act of shielding from danger, injury, destruction, or damage. The shepherd-leader 'would lie down in the gate physically to protect the sheep from wolves coming into the sheepfold. He literally put his life on the line for the sheep' (Simpson 2005). As Dykstra (2010) points out, this is one of the fundamental lessons one can learn from the great reformer, John Calvin:
The value for Calvin was, first, that he preached to real people, and specifically to God's people. He knew the needs and struggles of God's sheep. He understood, for example, that the theology and worship of Rome brought spiritual disaster to the people. It brought them into dread terror of God. It robbed them of the assurance of salvation. (p. 30)

Dykstra's (2010) allusion is to Book IV of Calvin's (1989) Institutes of the Christian religion, which is the epitome of Calvin's ecclesiology. Out of this ecclesiastical conviction, John Calvin went out to protect the masses from these spiritual savages and availed himself for the offensive.

John 10 teaches some important principles about being a good shepherd-leader. First of all, shepherd-leaders are to be watchmen. There are not only savage pseudo-leaders roaming the kosmos, there are savage leaders entering the oikos [God's household] at an alarming rate. Hence the apostolic warning: 'I know that after I leave, savage wolves will come in among you and will not spare the flock' (Ac 20:29).

The shepherd-leaders' under-performance regarding the sheep's protection is just as liable for the destruction caused under claimed episkopeō. The claimed leadership (selfish) that is not qualified by the capacity to lead always leads to failure. The true episkopeo is the one that harmonises with the assertion of Bruce L. Shelley (2008) that the:

pastor is a shepherd of souls, and the sheep are his flock - figures suggesting loving, sacrificial leadership. Both Peter and Paul link this shepherding ministry with the oversight of the Christian churches (Ac 20:28; 1 Pt 2:25). (p. 132)

This calls for leadership capacity and effectiveness (kyberneseis). It is clear then that 'selfish leaders ... melt like snowflakes when the heat is on. They do not persevere' (Strauch 2006:85).

God has ordained and commissioned every shepherd-leader an overseer. There are many gates into any ecclesiastical community, one of which is the people who come into the community but have an agenda to take people away from unity in the faith. Shepherd-leaders need to dedicate their lives in the gate to protect the flock at the risk of their reputations, friendships, their livelihood, and perhaps even their lives. There are too many hired hands in the local faith communes today who are sold out to sow the seed of compromise to the truth. By their inability to make the hard stands they make themselves useless to the Good Shepherd, and allow great evil a foothold under their watch.

In the same way, Jesus came to save his people from their sins (Mt 1:21). He 'came to seek and to save what was lost' (Lk 19:10). These are the salvific functions that are fulfilled in and by Jesus Christ. The soteriological scope includes Christ's searching initiatives; finding his lost humanity, and bringing them home, where they enjoy koinonia with both the Father and ecclesiastical community. 


\section{Courage}

This is one of the leadership qualities that every shepherdleader is expected to possess. It speaks of being of good cheer (tharseo ) in the face of threatening circumstances. Courage is a quality of spirit that enables one to face danger or pain without showing fear (Anonymous). It is correct to assume that courage entails ideas of boldness, confidence, and bravery. A discouraged leader leaves the sheep feeling vulnerable, insecure, and aimless. A courageous shepherdleader is reputable for the following.

\section{Assuming responsibilities}

These leaders do not embrace the paternalistic image of a leader or the flock. They put their lives at risk for the sake of the safety of the flock. They are not the hired hands that tend to abandon the flock when the enemy appears to destroy and kill the flock. The task of responsibility is not just for the leader's personal integrity, but is as Kuiper (1998:140) asserts: 'not only for dignity, but also for usefulness'.

\section{Courage to serve}

This means to fulfil a purpose, role, or function, to do duty or hold office; or to perform a specific function. It is to work for or be a servant to. In a nutshell, it is to be sufficient or adequate, either in quality or quantity.

\section{Courage to challenge}

This is boldness to face the demanding or the stimulating situation. The shepherd-leader is not afraid to take exception to issues (popular opposition) that may threaten the security or the courage of the sheep.

\section{Courage to participate in changing environment}

The shepherd-leader is proactive to change. This is a leader who is on the cutting edges of the changing context and the threatening environment of the sheep. According to Franklin (2009:412) 'leaders in God's mission must lead in a rapidly changing world - in social, cultural, economic, political and religious environments at local, national, and global levels'. The shepherd-leader participates in eschatological journey with the sheep, as he is also a human being still under construction. This shepherd-leader metaphor is clearly expounded in 1 Samuel 17:34-37:

But David said to Saul, 'Your servant has been keeping his father's sheep. When a lion or a bear came and carried off a sheep from the flock, I went after it, struck it and rescued the sheep from its mouth. When it turned on me, I seized it by its hair, struck it and killed it. Your servant has killed both the lion and the bear; this uncircumcised Philistine will be like one of them, because he has defied the armies of the living God. The LORD who delivered me from the paw of the lion and the paw of the bear will deliver from the hand of this Philistine.' Saul said to David, 'Go, and the LORD be with you.'

A shepherd-leader is not an effete figure. He needs and is expected to possess such courage as that of the young shepherd David in beating off cruel and unjust attackers.
He or she may be required to defend staff members from unfair and damaging accusations. This leadership position or role may demand readiness to confront false accusers and willingness to support victims of unjust attack. The fact remains that 'if you are not a positive encourager, you will probably be a poor admonisher' (Strauch 2006:149).

\section{Guidance}

The third major role of the shepherd-leader is that of guidance. It is to give direction or helpful suggestions regarding a decision or future course of action, the act of guiding or showing the way, the act of setting and holding a course. This is the fundamental function or the role of hodegos [leader or guide]. To hodegeo [to lead or to guide] in the Apocrypha seems to be more conspicuous than in the LXX. For instance, the noun appears in 1 Maccabees 4:2 to refer to the guides and for the pillar of fire in Wisdom 18:3. Whenever hodegeo appears parallel with didasko the meaning to teach is strong (Bromiley 1985:671). The New Testament uses hodegos in a literal sense. For instance in Acts 1:16, we read of Judas, who served as guide for those who arrested Jesus ... Jesus uses hodegos as a figure of speech in Matthew 23:16, 24 where the Pharisees are leaders of others but are themselves blind. In other New Testament texts (Rm 2:19; Mt 15:14; Rv 7:17; Ac 8:31; Jn 16:31) hodegos figuratively refers to giving an instruction, or leading to the goal of full truth.

In guiding the sheep, the shepherd is expected to be ready to exercise control over the sheep in order to guide and direct them to prevent them from wandering off into danger. The important piece of a shepherd's equipment, besides his rod to protect and defend the sheep, is his staff to guide and direct them. The staff is the ever-present symbol of the shepherd's authority. Its primary purpose is supervising, guiding and directing.

The community leaders are expected to lead their members in order to courteously exercise the authority to shape their behaviour. One community member may need to be nudged to the left and another to the right. In times of uncertainties, followers feel secure when leaders wield authority wisely, decisively, and assertively.

The shepherd-leader's function of caring, protecting, guiding and directing the flock requires courage. Though shepherd-leaders are required to act courageously, firmly and decisively, they are not expected to portray the harsh treatment of the sheep. The fundamental maxim is:

there is no place whatsoever for egotism in the Lord's work, especially for those who lead and teach the community of the cross. Yet arrogance is a widely recognised problem among leaders today. (Strauch 2006:55)

The Old Testament God is portrayed as a shepherd who sets the pattern:

- gathering his flock in his arms (Is 40:11)

- bandaging those that are hurt (Ezk 34:16)

- leading them to a place of refreshment (Ps 23). 
These images convey tenderness, nurture and devotion. In the New Testament:

we are told that the Good Shepherd (referring to Jesus) knows and cares for his sheep individually and that this care involves sacrificial depths: The good shepherd lays down his life for his sheep (Jn 10:11). (D'Souza 2000:45)

This fact is driven home by Strauch (2006:46) that 'kindness is a key to leading people effectively'.

\section{Conclusion}

The ecclesiastical leadership demands full understanding of the biblical model of shepherd-leadership, with the three major functions of caring, courage, and guiding the church in the most effective way. Those called to be shepherd-leaders in the communion of the saints must take that responsibility seriously. Further, according to Volf (1998:230), ' $t$ t]he task of leaders is first to animate all the members of the church to engage their pluriform charismatic activities, and then to coordinate these activities'. Leaders are the shepherds called to the responsibility for the mature church that is called to test every manifestation of the Spirit. Many claim to be called to servant leadership, but disqualified to be shepherds according to God's criteria. There is a great lesson of shepherd-leadership from John Calvin:

Calvin was nothing if not a preacher. Calvin is pre-eminently a model for Reformed pastors today insofar as Calvin was a preacher. He knew what fed the flock, kept the wolves at bay, ministered to the lambs, and gave muscles to the bones of the warriors ... and skill to their hands ... (Gritters 2009:19)

Shepherd-leaders need to strive for feeding the lambs and the sheep, bringing them to good pasture lands and water, grooming and clipping them, playing midwives for delivering new lambs, directing them and teaching them to stay in unity, seeking after the wandering lost ones, and protecting the sheep in the kosmos and in the oikos.

This is the core of leadership needed for charismatic assertion of ecclesia in the kosmos. The call is for leaders in the ecclesiastical community to emulate the shepherd-leader model for the advance and the effectiveness of the mission of Christ in the world. Leadership needs to adopt this model to partner with Christ in the continuing reformation of the church and humanity at large. The shepherd-leaders must become the syzygos [companion] with the Good Shepherd himself - Christ the kyrios [Lord] and the archipoimen [Chief Shepherd] of the flock.

The shepherd model enhances the Pauline body metaphor; and it is the focus of doing and living Christ in a mutual interconnectedness that enhances the communion ecclesiology. The shepherd and the sheep (leaders and followers) do life together for the benefit of each other, leading to ecclesia as a desirable incarnation of Christ in the world. The ecclesiastical community can creatively enhance the model by proposing various approaches in expressing their raison d'etre and their manifestation of their faith praxis.

\section{Acknowledgements Competing interests}

The author declares that he has no financial or personal relationship(s) that may have inappropriately influenced him in writing this article.

\section{References}

Anderson, A., 1972, The book of Psalms: New century Bible based on the revised standard version, vol. 1, Oliphants, Marshall, Morgan \& Scott, London.

Bible Study Planet, n.d., 3 Things the good Shepherd does, viewed 29 March 2014 from http://biblestudyplanet.com/3-things-the-good-shepherd-does-2/?

Bromiley, G.W., 1985, Theological dictionary of the New Testament, G. Kittel \& G. Friedrick (eds.), abridged in one volume, Wm.B. Eerdmans Publishing Company, Grand Rapids.

Calvin, J., 1989, Institutes of the Christian religion, transl. H. Beveridge, Wm.B. Eerdmans Publishing Company, Grand Rapids.

D'Souza, A.A., 2000, Leaders for today hope for tomorrow: Empowering and empowered leadership, Pauline Publications Africa, Nairobi.

Dykstra, R.J., 2010, 'John Calvin, the church reformer', Protestant Reformed Theological Journal 43(2), 30.

Franklin, K., 2009, 'Leading in mission at a higher level: How to become a reflective practitioner in mission leadership', Evangelical Missions Quarterly 45(4), 412-418.

Gritters, B.L., 2009, 'Calvin as model for Reformed ministers today', Protestant Reformed Theological Journal 43(1), 19.

Gray, E., n.d., 'Shepherd', in Holman Study Bible, viewed 29 March 2014, from http:// www.studylight.org/dic/hbd/view.cgi?number=T5746

Kuiper, R.B., 1998, The glorious body of Christ, The Banner of Truth Trust, Edinburgh.

Mugambi, J.N.K., 1995, From liberation to reconstruction: African Christian theology after the Cold War, East African Publishers, Nairobi.

Mwaura, P.N., 1994, 'Healing as a pastoral concern', in D.W. Waruta \& H.W. Kinoti (eds.), Pastoral care in African Christianity: Challenging essays in pastoral theology, pp. 62-86, Acton Publishers, Nairobi.

Peters, T., 2000, God - The world's future: Systematic Theology for a new era, Fortress Press, Minneapolis.

Pobee, J.S., 1992, 'In search of Christology in Africa', in Exploring Afro-Christology pp. 9-20, Peter Lang, Frankfurt.

Selderhuis, H.J., 2007, Calvin's theology of the Psalms, Baker Academic, Grand Rapids.

Shelley, B.L., 2008, 'The meaning of Church vocation', in J.D. Berkley (ed.), Leadership handbook of management and administration, pp. 129-141, rev. \& expanded edn., Baker Books, Grand Rapids.

Simpson, S., 2005, 'The responsibilities of a good shepherd', in Apologetics Coordination Team (ACT), viewed 29 March 2014, from http://www.deceptioninthechurch. com/agoodshepherd.html?

Strauch, A., 2006, A Christian leader's guide to leading with love, Lewis and Roth Publishers, Littleton.

Tenney, M.C., 1975, John - The Gospel of belief: An analytical study of the text, Wm. B. Eerdmans Publishing Company, Grand Rapids.

Vine, W.E., 1952, An expository dictionary of New Testament words with their precise meanings for English readers, Riverside Book and Bible House, lowa Falls.

Volf, M., 1998, After our likeness: The church as the image of the trinity, Wm. B. Eerdmans Publishing Company, Grand Rapids.

Weaver, D.J., 2009, 'They did to Him whatever they pleased': The exercise of political power within Matthew's narrative', HTS Teologiese Studies/Theological Studies 65(1), 9 pages. http://dx.doi.org/10.4102/hts.v65i1.319

Wright, C.J.H., 2001, The message of Ezekiel: A new heart and a new spirit, InterVarsity Press, Nottingham. 